\title{
Physiological and Biochemical Behaviour of Gleditsia triacanthos L. Young Seedlings Under Drought Stress Conditions
}

\author{
Salima KEBBAS ${ }^{1,2 *}$, Torkia BENSEDDIK ${ }^{2}$, Hakima MAKHLOUFI ${ }^{2}$, \\ Fatiha AID ${ }^{2}$ \\ ${ }^{1}$ University Saad Dablab Blida 1 (USDB1), Faculty of Life and Natural Sciences, Department of Biology of Populations of Organisms, \\ BP 270 route de Soumaa, 09100, Blida, Algeria; selmakebbas@yahoo.fr (*corresponding author) \\ ${ }^{2}$ University of Sciences and Technology Houari Boumediene (USTHB), Faculty of Biological Sciences, Laboratory of Biology and \\ Physiology of Organisms, Plant Physiology Group, BP 32 El Alia, 16111, Bab Ezzouar, Algiers, \\ Algeria; toukbens@gmail.com; hmakh96@gmail.com;faid@usthb.dz
}

\begin{abstract}
Drought affects a wide part of the world and constitutes one of the most important limiting factors for growth and development of vegetation cover. Plants evolved several physiological and biochemical mechanisms to cope with biotic and abiotic stresses. Gleditsia L. (Fabaceae) is a small genus of typically spiny trees native to America, Asia, and Africa. Among this genus Gleditsia triacanthos L. belongs to drought-tolerant species and could be a long-term solution for reforestation of dry land areas. The aim of our work is to study the impact water stress on G. triacanthos plants at early stage of development. After six weeks of culture, water stress was imposed during 19 days. A gradual dehydration of the soil caused a progressive drop in the relative water content (RWC) down to $60.54 \pm 2.06 \%$ at the end of treatment. On the other hand, G. triacanthos young seedlings show an important osmotic adjustment by an early accumulation of proline. The phenylpropanoids metabolism was also affected by water stress where a significant increase in total polyphenols, total flavonoids and anthocyanin concentrations was recorded. These compounds could play a dual role both in osmoregulation mechanism and antioxidant system. $G$. triacanthos stressed plants appear to protect its photosystems by increasing carotenoids rate and maintain a stable $\mathrm{Chl} a / b$ ratio despite a substantial decrease in chlorophyll pigments $(\mathrm{Chl} a+b)$ content.
\end{abstract}

Keywords: drought; osmotic adjustment; pigment; polyphenols; proline

Abbreviations: $\mathrm{Chl} a+b$ : total chlorophyll content; $\mathrm{Chl} a / b$ : Chlorophyll $a / C h l o r o p h y l l ~ b$ ratio; Cyd-3-Glu: Cyanidin-3Glucosid; DW: Dry Weight; FW: Fresh Weight; GAE: Gallic Acid Equivalent; RWC: Relative Water Content; TW: Turgid Weight

\section{Introduction}

The natural environment of plants is composed of a complex set of abiotic stresses and biotic stresses. Abiotic stresses limit crop productivity and play a major role in determining the distribution of plant species across different types of environments (Kramer and Boyer, 1997; Araus et al., 2008; Cramer et al., 2011).

Drought, defined as the occurrence of a substantial water deficit in the soil or in the atmosphere, is an alarming constraint to crop productivity and yield stability worldwide. It is the leading environmental stress in world agriculture, causing losses in crop yield probably exceeding losses from all other causes combined. Drought stress adversely affects a variety of vital physiological and biochemical processes in plants, leading to reduce growth and productivity (De Oliveira et al., 2012).

In return, plants have evolved mechanisms to cope with the stress; such adaptive mechanisms are the results of a multitude of morpho-anatomical, physiological, biochemical, and molecular changes. Among those adaptations, osmoregulation is the most common physiological one, which takes place by reducing cellular water potential and allowing the maintenance of the turgor of the plant under stress. This adjustment involves the accumulation of compatible osmoprotectants such as sugars, nitrogen compounds and compounds derived from 
586

secondary metabolism, including polyphenols (Mattoo et al., 2015). As a consequence, such plants are able to take up water from a low water potential medium to sustain normal or near normal physiological processes necessary for growth and development (Medrano et al., 2002; Pinheiro and Chaves, 2011; De Oliveira et al., 2012)

Gleditsia triacanthos L. commonly named: honey locust belongs to Caesalpinioideae subfamily of the monophyletic Caesalpinioid crown clade. It is a medium-sized tree legume characterized by moderate to rapid growth rates, drought tolerance, shade intolerance, and contain thorns that are modified shoots in honey locust (Gailing et al., 2017).

This genus is native to the temperate and subtropical regions of North America (Nebraska, Pennsylvania, and Texas), South Asia and Africa. It occurs in a wide range of habitats, from rich bottomlands to nutrient-poor rocky slopes and other marginal habitats (Preston and Braham, 1998; Schnabel and Wendel, 1998). It was first introduced in England and used in many Europeans countries as an ornamental tree able to support strong air pollution, but is also used to form thorny hedges. It was introduced in Algeria under the name "Acacia" and was quickly used as forage, shelterbelt, and thorny hedges and to limit plots of grazed lands. Honey locust is an insect pollinated and mainly out crossing species with an effective long distance gene flow by pollen (Schnabel and Hamrick, 1995), even in highly fragmented landscapes (Owusu et al., 2016).

Honey locust forage has no apparent toxic effects to livestock and had one of the highest ruminal digestibility and nitrogen availability among ten hardwood species tested (Baertsche et al., 1986; Addlestone et al., 1999). Its fresh leaves are particularly appreciated by cattle and rabbits. The fresh pods are eaten as delicacies, whereas the dry ones are less appreciated.

Deep-rooted, perennial trees such as honey locust could represent a particular niche for rotational livestock browse when drought limits forage options and livestock productivity, as it is demonstrated for the subMediterranean region (Papanastasis et al., 1998).

The species is rich in alkaloids, flavonic pigments, and tanning agents (Turova, 1974). It is used in folk medicine for spastic colitis, chronic cholecystitis, stomach ulcers, bronchial asthma (Rakhmanberdyeva et al., 2002). Its fruits and thorns are used to treat apoplexy, headache, productive cough, asthma and suppurative skin diseases (Mohammed et al., 2014).

Most of the Algerian territory (87\%) is a desert, where precipitation is almost zero and the plant resources are very poor. The arid and semi-arid zones of the steppe regions constitute a real buffer between coastal and Saharan territories and play a fundamental role in the country's agricultural economy. These arid zones are increasingly the target of enlarged desertification and anthropogenic pressure: overgrazing, exploitation of land unsuitable for cultivation. This land degradation and desertification is the most advanced stage, resulting in the reduction of biological potential and the breakdown of ecological and socioeconomic equilibrium. Despite a rarefaction of the vegetation cover, non-succulent perennial species constitute the majority of plants in these regions (Nedjraoui and Bedrani, 2008).
Therefore, various strategies have been proposed for the rehabilitation of those areas under drought conditions. These strategies require the identification of droughtresistant species that are valuable resources for the future as they exhibit eco-physiological traits and genetic adaptations allowing them to sustain water shortage (Kacimi, 1996; MARD, 2007; PDRA, 2010; PDRA, 2013).

G. triacanthos is very resistant to drought since it can be found on sterile lands of central Kentucky and it is recognized as one of the best trees for windbreaks in large plains. In Algeria, the Forest Service (Defence and Soils Restoration) thought about using this species for the reconstitution of the sylvo pastoral cover of important areas (Putod, 1982).

Due to both economic and ecological importance of this species, the analysis of the biochemical and physiological mechanisms of resistance to drought in seedling $G$. triacanthos, which is one of the most critical stages in the life cycle of plants, constitute the most important purpose of this research.

\section{Materials and Methods}

\section{Culture conditions}

G. triacanthos seeds were collected in the region of Sidi

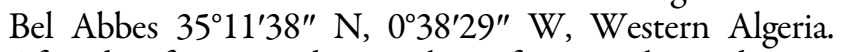
After disinfection and manual scarification, the seeds were germinated in an oven at $27^{\circ} \mathrm{C}$ in the dark and the seedlings were transferred into plastic pots $(10 \times 10 \mathrm{~cm})$ felled with loam (Loam for Professionals, DCM N.V., Grobbendonk, Belgium), with one seedlings per pot, watered daily with tap water.

The experiments were performed on seedlings of the same stage of development, on which the first four leaves were collected for all measurements. G. triacanthos seedlings, 6 weeks old, were separated into two groups: the first batch of plants is considered as controls and seedlings were well watered daily with tap water. The second batch of plants undergoes a watering stop. The leaves were harvested at different intervals of time (the $4^{\text {th }}, 9^{\text {th }}, 13^{\text {th }}, 16^{\text {th }}$ and the $19^{\text {th }}$ day of stress). Five plants per treatment were used for each measurement.

\section{Measurement of Relative Water Content (RWC)}

The relative water content (RWC) was measured according to the method of Barrs and Weatherleyt (1968), calculated according to the formulas:

$$
\text { RWC }=[\text { FW-DW } / \text { TW-DW }] \times 100 \text {, }
$$

where: (FW) fresh weight; (DW) dry weight and (TW) turgid weight or weight at full turgor. It was determined by placing two leaves samples in $30 \mathrm{~mL}$ sealed tubes containing distilled water, and allowing the samples to reach full turgor in darkness overnight at $4^{\circ} \mathrm{C}$.

\section{Extraction and determination of proline}

Fresh plant material $(200 \mathrm{mg})$ is cold milled of in $3 \mathrm{~mL}$ of sulfo-salicylic acid. The extract was centrifuged at 9,000 $\mathrm{rpm}$ for $15 \mathrm{~min}$. Proline is then assayed according to the method adapted from Troll and Lindesly (1955), simplified by Bates (1973). 


\section{Determination of chlorophyll pigments}

Chlorophyll pigments and total carotenoids were determined from whole leaves. $0.1 \mathrm{~g}$ of fresh plant material was ground in $10 \mathrm{~mL}$ of $80 \%(\mathrm{~V} / \mathrm{V}$ ) acetone in order to extract all of the chlorophyll pigments. The extract was centrifuged at 3,000 g for $10 \mathrm{~min}$. The absorbance of the extract is measured at $647 \mathrm{~nm}$ for chlorophylls $a$ and 663 $\mathrm{nm}$ to chlorophylls $b$ and $470 \mathrm{~nm}$ for carotenoids. The concentrations of chlorophylls and carotenoids, expressed in $\mathrm{mg} \mathrm{g}^{-1}$ DW were calculated according to Lichtenthaler (1987).

\section{Assays of total polyphenols}

The determination of total polyphenols was carried by the method using the Folin-Ciocalteu reagent according to Singleton and Rossi (1965). Fresh plant materials (0.3 g) were ground in ice. $2 \mathrm{~mL}$ of $80 \%$ methanol was added to the homogenate, and the extract was centrifuged at 13,000 rpm for $30 \mathrm{~min}$. After centrifugation, the supernatant containing polyphenols was recovered. A mix of $0.25 \mathrm{~mL}$ of the supernatant, $0.25 \mathrm{~mL}$ of Folin-Ciocalteu reagent and 0.5 $\mathrm{mL}$ of bicarbonate $\left(\mathrm{CO}_{3} \mathrm{Na}_{2}\right) 20 \%$ were introduced in tubes and the volume was completed to $5 \mathrm{~mL}$ with distilled water. A blank was prepared under the same conditions with $80 \%$ methanol instead of plant extract solution. The tubes were incubated at $25^{\circ} \mathrm{C}$ for $20 \mathrm{~min}$ in the darkness. The optical density was measured at $735 \mathrm{~nm}$. The results were expressed in $\mathrm{g} \mathrm{mg}^{-1}$ of gallic acid per $\mathrm{g}$ of DW according to the following equation $(y=0.012 x-0.0345 ; \mathrm{R}=0.099)$.

\section{Determination of total flavonoids}

Total flavonoids were determined using the method of Dewanto et al. (2002) using Aluminium trichloride and sodium hydroxide. Aluminium trichloride forms a yellow complex with flavonoids and Sodium hydroxide forms a pink complex that absorbs in the visible at $510 \mathrm{~nm}$. The standard curve was prepared from catechin stock solution at $1 \mathrm{~g} \mathrm{~mL}^{-1}$. The dilutions prepared varied from 50 to $500 \mathrm{mg}$ $\mathrm{mL}^{-1}$. The absorbance was read at $510 \mathrm{~nm}$ at the spectrophotometer (UV-1800, Shimadzu).

\section{Determination of anthocyanins}

The anthocyanins were extracted according to the method of Pietrini et al. (2002). The absorbance was read on a clear supernatant at 530 and $657 \mathrm{~nm}$, taking into account the interference with the chlorophylls. Anthocyanins were measured according to the protocol of Mancinelli (1984) using equation $\mathrm{A}_{530}-0.25 . \mathrm{A}_{657}$ and the anthocyanin contents were expressed in equivalent amount of Cyanidine-3-glucoside per $100 \mathrm{~g}$ dry weight using its molar extinction coefficient $\left(29,600 \mu \mathrm{mol}^{-1} \mathrm{~cm}^{-1}\right)$ and its molecular weight of $449.2 \mathrm{~g} \mathrm{~mol}^{-1}$.

\section{Statistical analysis}

The statistical analysis was performed using SPSS (Version 20.0, IBM SPSS Statistic). Data were analyzed using a one-way analysis of variance $(A N O V A)$ at a significant level of $P<0.05, P<0.01$, and $P<0.001$ considering the presence or absence of stress as a factor. The statistical significance of the results was analyzed by the Tukey's HSD test (Honest Significant Difference).

\section{Results and Discussion}

\section{Leaf water status}

G. triacanthos foliar Relative Water Content (Fig. 1) of control seedlings was almost constant during 19 days of the experiment around $90.43 \pm 2.57 \%$, because the amount of water lost in the process transpiration from leaves seems to be quickly recovered from the regularly watered soil through the roots. In stressed plants, RWC decreases as stress intensifies. The relative water content reaches $70.25 \pm$ $1.54 \%$ and $60.54 \pm 2.06 \%$ respectively after 16 and 19 days of water stress. Significant differences between controls and drought treatments occur from the $4^{\text {th }}$ day after initiation of stress $(p<0.01)$.

\section{Photosynthetic pigments}

The Chl $a+b$ content was expressed in $\mathrm{mg} \mathrm{g}^{-1}$ of DW (Fig. 2A). We observed a decline in chlorophyll photosynthetic pigments $(\mathrm{Chl} a+b)$ in stressed plants, from $18.71 \pm 0.62 \mathrm{mg} \mathrm{g}^{-1} \mathrm{DW}$ in the first day of experiment to $2.16 \pm 0.26 \mathrm{mg} \mathrm{g}^{-1} \mathrm{DW}$ on the $19^{\text {th }}$ day of stress. The chlorophyll pigments of the control plants showed stable content around $20.66 \pm 3.49 \mathrm{mg} \mathrm{g}^{-1} \mathrm{DW}$. Significant differences were noticed between controls and stressed plants from the $9^{\text {th }}$ day of the water stress $(p<0.01)$ and were maintained until the end of the experiment. Despite this significant decrease in chlorophyll pigment, the $\mathrm{Chl} a / b$ ratio was not affected by water stress (Fig. 2B).

On the other hand, carotenoid contents (Fig. 2C) increased in G. triacanthos stressed plants at the end of the experimental period $\left(16^{\text {th }}\right.$ and $19^{\text {th }}$ day of stress).

\section{Osmotic adjustment}

Proline content in G. triacanthos plants increased throughout the experiment both in control and stressed plants (Fig. 3A). In control plants, this increase could be due to the phenomenon of senescence (Wang, 1982). However, proline levels remain significantly lower than the levels of stressed plants, which exhibit a drastic increase in this

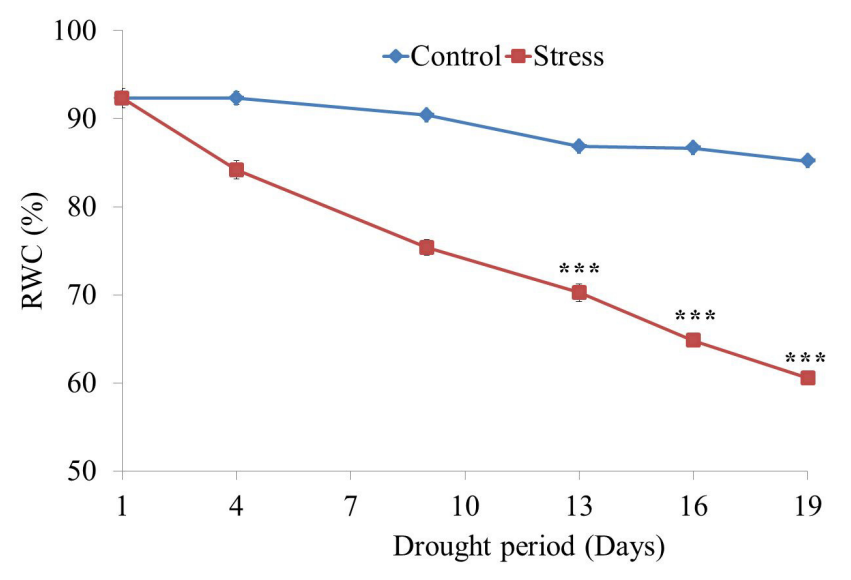

Fig. 1. Evolution of Gleditsia triacanthos L. Relative Water Content (RWC) under control and water stress conditions. Mean \pm SE $(n=5)$. Significant difference from control at ${ }^{*} \mathrm{p}<$ $0.05,{ }^{* *} \mathrm{p}<0.01$ or $^{* * *} \mathrm{p}<0.001$ by Tukey's multiple test 

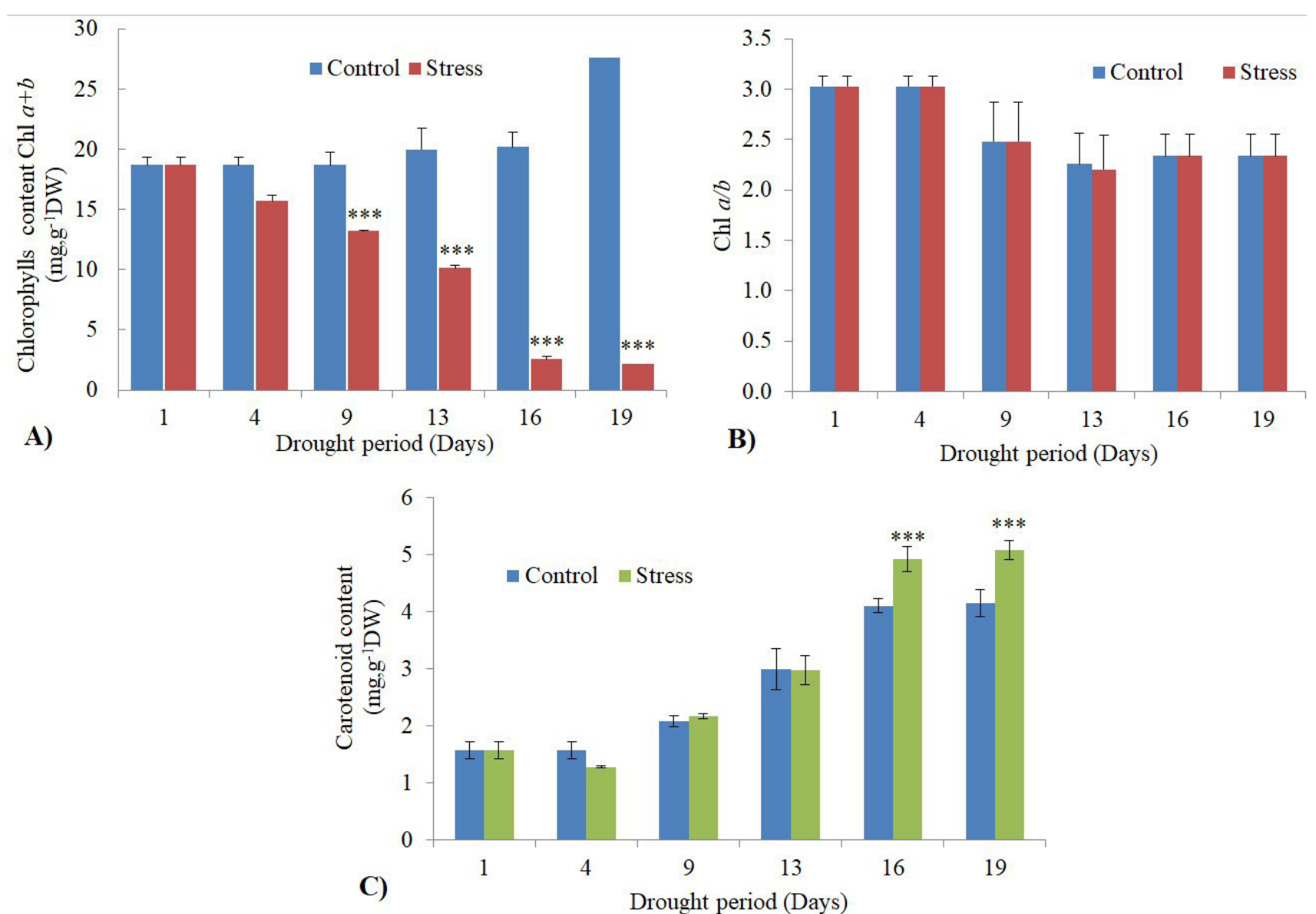

Fig. 2. Evolution of Gleditsia triacanthos $\mathrm{L}$. photosynthetics pigments under control and water stress conditions: (A) Chl $a+b$, (B) ratio Chl $a / b,(C)$ Total carotenoids. Mean \pm SE $(\mathrm{n}=5)$. Significant difference from control at ${ }^{*} \mathrm{p}<0.05,{ }^{* *} \mathrm{p}<0.01$ or ${ }^{* * *} \mathrm{p}<$ 0.001 by Tukey's multiple test

osmolyte that reached $56.20 \pm 2.03 \mathrm{mg} \mathrm{g}^{-1} \mathrm{DW}$ in the $19^{\text {th }}$ day of stress. This is a 20 -fold increase over the first day of stress.

The rate of total polyphenols, total flavonoids and anthocyanins of $G$. triacanthos (Fig. 3B-D) control plants increased slightly with time; in stressed plants, the rate of polyphenols increased steadily and more strongly (Fig. 3B) from $99.10 \pm 1.0 \mathrm{mg} \mathrm{GAE} \mathrm{g}^{-1} \mathrm{DW}$ at the $4^{\text {th }}$ day of stress to $159.53 \pm 1.22 \mathrm{mg} \mathrm{GAE} \mathrm{g}^{-1} \mathrm{DW}$ at the $19^{\text {th }}$ day of the experiment. The figure 3C shows a stable increase in flavonoids content passing from $5.32 \pm 0.05 \mathrm{mg} \mathrm{g}^{-1} \mathrm{DW}$ the $4^{\text {th }}$ day to $9.70 \pm 0.29 \mathrm{mg} \mathrm{g}^{-1} \mathrm{DW}$ at the $19^{\text {th }}$ day of experimentation and the anthocyanins (Fig. 3D) varied from $11.68 \pm 0.37 \mathrm{mg}$ Cyd-3-Glu. $\mathrm{g}^{-1} \mathrm{DW}$ on the $4^{\text {th }}$ day to $94.94 \pm 1.38 \mathrm{mg}$ Cyd-3-Glu. $\mathrm{g}^{-1} \mathrm{DW}$ at the $19^{\text {th }}$ day of treatment.

Water is a key determinant of plant growth, particularly in arid and semi-arid regions (Clarck and Mac-Caig, 1982). As water deficit induces a decrease in the relative water content in stressed plants, this parameter can be used as an important indicator of the plant hydric state under stress conditions (Albouchi et al., 2000).

In G. triacanthos the RWC of stressed leaves decreased at the end of the experiment when the amount of water in soil was insufficient to replace the one that has been evaporated from the leaves.
Many parameters divided in intrinsic and extrinsic ones may influence leaf chlorophyll pigments amount .These parameters are respectively related to plant traits as age and position of the leaves and to environmental factors such as light, temperature, and water availability (Hikosaka et al., 2006). However, the behaviour of plant pigment differs from a species to other. In nature, several species degrade chlorophylls under stress conditions; they are described as sensitive plants. A second category of plants, retain their chlorophyll levels during the drought period. Species like Barya nitida, Acacia raddiana and Parkinsonia aculeata were able to maintain their content of chlorophylls during rapid dehydration (Hethzerington and Smillie, 1982; Kebbas et al., 2015; Lassouane $e t$ al., 2016). Under water stress, a decrease in chlorophyll content was also observed in Acacia arabica water stressed young seedlings (Lassouane $e t$ al., 2013).

The reduction of Chl $a+b$ in stressed plants of $G$. triacanthos. can be explained by a decrease in the thylakoidal proteins associated with chlorophyll $a$ and $b$. This reduction is due either to a weak synthesis of proteins or to an activation of their degradation (Meribai, 2004). It may also be due to chlorophylls degradation and a reduction in their synthesis. The decrease in chlorophyll content under drought stress can be considered as a typical symptom of 

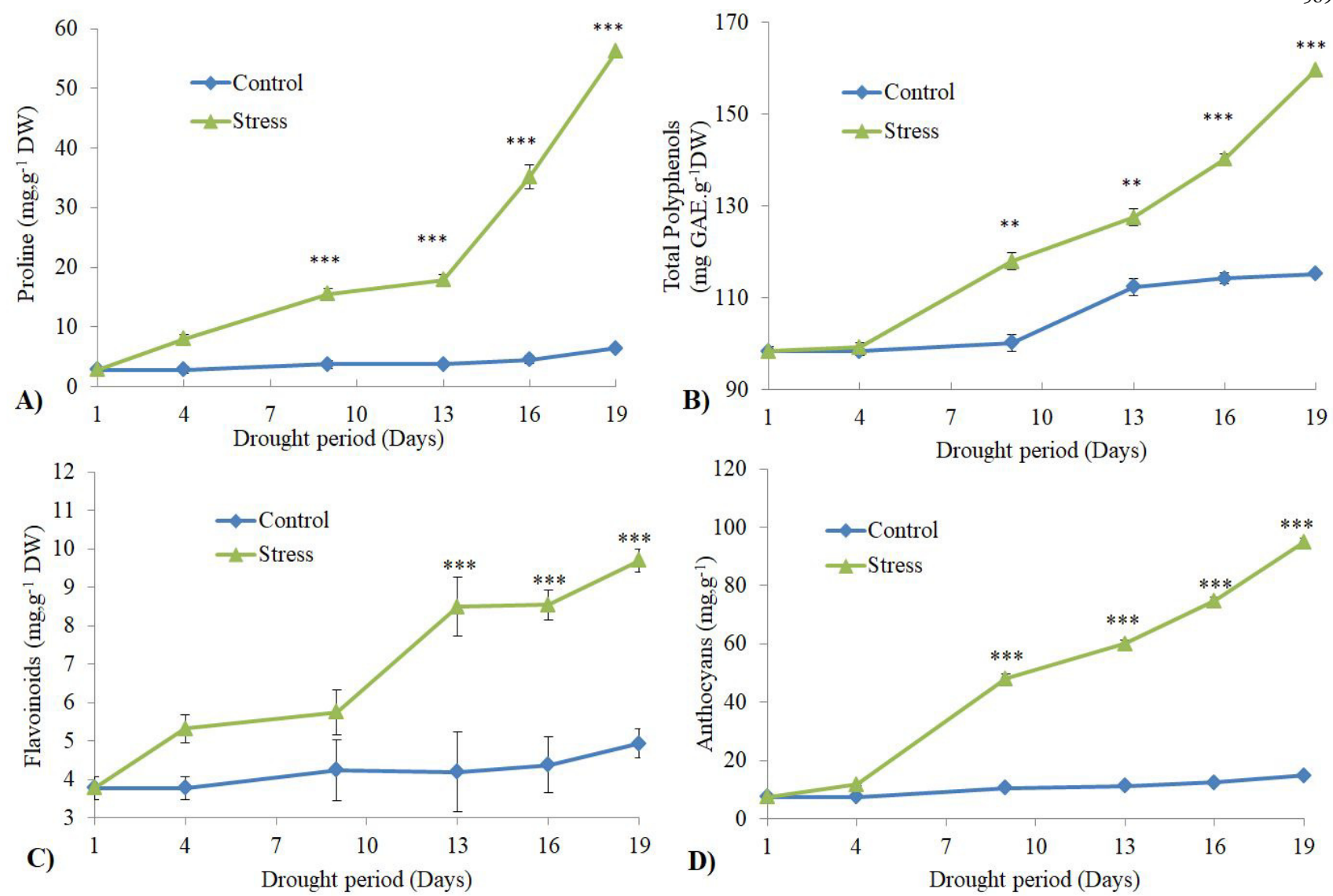

Fig. 3. Osmotic adjustment in Gleditsia triacanthos L.: Evolution of (A) Proline, (B) Total polyphenols, (C) Total flavonoids and (D) Anthocyanins under control and water stress conditions. Mean $\pm \mathrm{SE}(\mathrm{n}=5)$. Significant difference from control at ${ }^{*} \mathrm{p}<0.05$, ${ }^{* *} \mathrm{p}<0.01$ or ${ }^{* * *} \mathrm{p}<0.001$ by Tukey's multiple test

oxidative stress and may be the result of pigment photooxidation and chlorophyll degradation. Otherwise, the Chl $a / b$ ratio has not been affected by drought suggesting that the photosynthetic apparatus could be relatively stable even under severe drought conditions and $G$. triacanthos plants had probably evolved photoprotections mechanisms.

In addition, $G$. triacanthos seedlings, showed an increase in carotenoid content under drought stress, which are known to be photoprotective pigments. They participate actively in the proper functioning of plants by mechanisms, such as the xanthophylls cycle that protects plants from excess light and heat. Carotenoids can directly deactivate singlet oxygen, dissipate excess energy, and indirectly reduce forms of superoxide anion $\left(\mathrm{O}^{-2}\right)$ (Foyer et al., 1994).

The increase of proline content and the accumulation of polyphenols compounds constitute the main osmotic adjustment in G. triacanthos stressed plants. These results are also observed in Parkinsonia aculeata seedlings, where the raise in the amount of proline was correlated to the decrease in relative water content, and this increase was steady and related to the intensity of stress (Benadjaoud and Aid, 2012). During stress, the proline level can be as much as 100-fold higher than in normal conditions (Lipiec, 2013). In G. triacanthos stressed plant proline level was 8fold higher than in control plants at the last day of treatment $(\mathrm{d} 19)$.
Proline may differently affect stress tolerance, increase the activity of many enzymes, and stabilize protein integrity (Szabo and Savoure, 2010; Lipiec et al., 2013). The accumulation of proline in dehydrated seedlings is the consequence of the activation of the proline biosynthesis and inhibition of its degradation (Nakashima, 1998)

Proline accumulation facilitate water uptake (Ashraf and Foolad, 2007; Miller et al., 2010) to ensure osmotic adjustment which is the main physiological characteristics of tolerance (Clarke, 1987; Manivannan et al., 2008) .This adjustment allows the maintenance of cell turgor at the highest possible level for low water potentials thus maintaining photosynthesis, membranes and growth (Turner, 1989; Lawlor and Cornic, 2002).

In addition to osmotic adjustments, proline was suggested to be important for protecting cells against increased levels of Reactive Oxygen Species (ROS) accumulation under stress conditions. It was established that proline indirectly protect the photosystem and scavenge ROS during drought (Miller et al., 2010).

The biosynthesis of phenolic compounds in plants is generally induced in response to biotic and abiotic stimuli such as UV-B radiation, drought, cold, ozone, heavy metals, pathogen attacks, or nutrient deficiencies (Dixon and Paiva, 1995; Grace, 2005). They are also involved in stress acclimation in plants (Rivero et al., 2001; Parida et al., 2007). 
590

Our results showed that $G$. triacanthos stressed plants accumulate phenolic and flavonoids (anthocyanins) compounds which are known for their anti-oxidant (antifree radical), and anti-senescence roles.

It was reported that $G$. triacanthos seed extracts can be used as a natural source of phenolic compounds and as antioxidants (Cerqueira et al., 2010; Mohammed et al., 2014).

Similar results were reported by Chakhchar et al. (2015) in Argania spinosa. The accumulation of phenolic compounds and flavonoids have also been detected in response to drought in two Phaseolus vulgaris cultivars that accumulate total phenols and flavonoids in response to rather severe drought conditions, even after 22 days of water stress (Rosales et al., 2012). Such results show that water stress can induce the pathways of shikimate and phenylpropanoids in stress resistant plants (Dixon and Paiva, 1995). Kebbas (2016) reported an important accumulation of polyphenols correlated to an activation of the Phenylalanine ammonia lyase in Acacia raddiana stressed seedlings. Tattini et al. (2004) hypothesised that antioxidant flavonoids have protective functions during drought stress. Polyphenols are thus involved in the maintenance of osmotic potential, as well as in the trapping of free radicals under water stress (Chakhchar $e t$ al., 2015).

\section{Conclusions}

G. triacanthos young seedling subjected to a progressive dehydratation showed a gradual decrease of the RWC. Despite an important decrease in chlorophyll pigment, it seems that $G$. triacanthos seedling protect their photosystem apparatus by increasing carotenoids rate and maintain a stable $\mathrm{Chl} a / b$ ratio. Otherwise, $G$. triacanthos young seedlings show an important osmotic adjustment by the accumulation of proline and polyphenols compounds. These compounds accumulation is an effective way to allow a better osmotic adjustment of cells and therefore a better resistance to osmotic stress. The analyse on the anti-oxidant mechanisms implemented by this species would be interesting for our future researches. We can conclude that the future use of $G$ triacanthos, could be crucial for the reforestation and rehabilitation of the semi-arid zones due to the ability of this species to adaptation to climatic conditions of such areas.

\section{Acknowledgements}

This research received no specific grant from any funding agency in the public, commercial, or not-for-profit sectors.

\section{References}

Araus JL, Slafer GA, Royo C, Serret MD (2008). Breeding for yield potential and stress adaptation in cereals. Critical Reviews in Plant Sciences 27:377-412.

Addlestone BJ, Mueller JP, Luginbuhl JM (1999). The establishment and early growth of three leguminous tree species for use in silvopastoral systems of the southeastern USA. Agroforestry System
44:253-265.

Albouchi A, Sebei H, Mezni MY, EL Aouni MH (2000). Influence de la durée d'une alimentation hydrique déficiente sur la production de biomasse, la surface transpirante et la densité stomatique d'Acacia cyanophylla [Influence of the duration of a deficient water supply on the biomass production, the transpiring surface and the stomatal density of Acacia cyanophylla]. Annals of INRGREF 4:138-161.

Ashraf M, Foolad MR (2007). Roles of glycine betaine and proline in improving plant abiotic stress resistance. Environmental and Experimental Botany 59:206-216.

Baertsche SR, Yokoyama MT, Hanover JW (1986). Short rotation, hardwood tree biomass as potential ruminant feed chemical composition, nylon bag ruminal degradation and ensilement of selected species. Journal of Animal Science 63:2028-2043.

Barrs HD, Weatherleyt PE (1968). A Re-Examination of the Relative Turgidity Technique for Estimating Water Deficits in Leaves. Australian Journal of Biological Sciences 15(3):413-428.

Bates LS, Waldren RP, Teare ID (1973). Rapid determination of free proline for water-stress studies. Plant Soil 39:205-207.

Benadjaoud A, Aïd F (2012). Réponse adaptative des plants de Parkinsonia aculeata L à une contrainte osmotique. [Adaptive response of Parkinsonia aculeata seedlings to osmotic constrain]. Algerian Journal of Arid Environment 2(2):88-93.

Cerqueira MA, Souza BWS, Martins JT, Teixeira JA, Vicente AA (2010). Seed extracts of Gleditsia triacanthos: functional properties evaluation and incorporation into galactomannan films. Food Research International 43:2031-2038.

Chakhchar A, Lamaoui M, Wahbi S, Ferradous A, El Mousadik A, Ibnsouda-Koraichi S, Filali-Maltouf A, El Modafar C (2015). Leaf water status, osmoregulation and secondary metabolism as a model for depicting drought tolerance in Argania spinosa. Acta Physiologiae Plantarum 37:1-16.

Clarck JM, Mac-Caig TN (1982). Excised leaf water relation capability as an indicator of drought resistance of Triticum genotypes. Canadian Journal of Plant Science 62:571-576.

Clarke JM (1987). Use of physiological and morphological traits in breeding programmes to improve drought resistance of cereals. In: Srivastava JP, Porceddu E, Acevedo E, Varma S (Eds). Drought Tolerance in Winter Cereals. John Wiley and Sons, UK pp 171189.

Cramer GR, Urano K, Delrot S, Pezzotti M and Shinozak K (2011). Effects of abiotic stress on plants: a systems biology perspective. BMC Plant Biology 11:163.

De Oliveira AB, Alencar MNL, Gomes-Filho E (2012). Physiological and biochemical responses of semiarid plants subjected to water stress. In: Mofizur Rahman IM, Hasegawa H (Eds). Water Stress. IntechOpen, Croatia pp 43-59.

Dewanto V, Wu X, Adom K, Liu RH (2002). Thermal processing enhances the nutritional value of tomatoes by increasing total antioxidant activity. Journal of Agricultural and Food Chemistry 50:3010-3014.

Dixon RA, Paiva NL (1995). Stress-induced phenylpropanoid metabolism. Plant Cells 7:1085-1097. 
Foyer CH, Descourvieres P, Kunert KJ (1994). Protection against oxygen: An important defence mechanism studied in transegenic plants. Plant Cell and Environment 17:507-523.

Gailing O, Staton ME, Lane T, Schlarbaum SE, Nipper R, Owusu SA, Carlson JE (2017). Construction of a Framework Genetic Linkage Map in Gleditsia triacanthos L. Plant Molecular Biology Reporter 35:(2)177-187.

Grace S (2005). Phenolics as antioxidants In: Smirnoff N (Ed). Antioxidants and Reactive Oxygen Species in Plants. Blackwell, Oxford pp 141-168.

Hethzerington SE, Smillie RM (1982). Humidity-sensitive degreening and regreening of leaves of Bory a nitida Labill as followed by changes in chlorophyll fluorescence. Australian Journal of Plant Physiology 9(5):587-599.

Hikosaka K, Ishikawa K, Borjigidai A, Muller O, Onoda Y (2006). Temperature acclimation of photosynthesis: mechanisms involved in the changes in temperature dependence of photosynthetic rate. Journal of Experimental Botany 57:291-302.

Kacimi B (1996). La problématique du développement des zones steppiques. Approche et perspectives [The problematic development of steppe areas. Approach and perspectives]. Doc. HCDS, Ministère de l'agriculture, Algeria.

Kebbas S, Lutts S, Aid F (2015). Effect of drought stress on the photosynthesis of Acacia tortilis subsp. raddiana at the young seedling stage. Photosynthetica 53:288-298.

Kebbas S (2016). Contribution à l'étude de la physiologie d'Acacia tortilis Forssk. subsp raddiana Savi: Effet du déficit hydique [Contribution to the study of the physiology of Acacia tortilis Forssk. subsp raddiana Savi: Effect of water deficit ]. $\mathrm{PhD}$ Thesis, University of Sciences and Technology Houari Boumediene, Algiers.

Kramer PJ, Boyer JS (1997). Water relations of plants and soils. Academic Press, San Diego, USA.

Lassouane N, Aï F, Lutts S, (2013). Water stress impact on young seedling growth of Acacia arabica. Acta Physiologiae Plantarum 35:2157-2169.

Lassouane N, Aï F, Lutts S (2016). Drought inhibits early seedling establishment of Parkinsonia aculeata L. under low light intensity: a physiological approach. Plant Growth Regulation 80(2):115-126.

Lawlor DW, Cornic G (2002). Photosynthetic carbon assimilation and associated metabolism in relation to water deficits in higher plants. Plant Cell and Environment 25:275-294.

Lipiec J, Doussan C, Nosalewicz A, Kondracka K (2013). Effect of drought and heat stresses on plant growth and yield: a review. International Agrophysics 27:463-477.

Lichtenthaler HK (1987). Chlorophylls and carotenoids: Pigments of photosynthetic biomembranes. Methods in Enzymology 148:350382.

Mancinelli AL (1984). Photoregulation of anthocyanin synthesis: Effect of light pretreatments. Plant Physiology 75(2):447-453.

Manivannan P, Abdul Jaleel C, Somasundaram R, Panneerselvam R (2008). Osmoregulation and antioxidant metabolism in drought stressed Helianthus annuus under triadimefon drenching. Comptes Rendus de Biologie 331(6):418-425.
Mattoo AK, Upadhyay RK, Rudrabhatla S (2015). Abiotic stress in crops: Candidate genes, osmolytes, polyamines, and biotechnological intervention. In: Pandey GK (Ed). Elucidation of Abiotic Stress Signaling in Plants. Springer Science, New York pp 415-437.

Medrano H, Escalona J, Bota J, Gulias J, Flexas J (2002). Regulation of photosynthesis of $\mathrm{C} 3$ plant in response to progressive drought: stomatal conductance as a reference parameter. Annals of Botany 89:895-905.

Meribai S (2004). Evolution de la proline et des chlorophylles des semis de chêne liège (Quercus suber $L$ ) soumis à des températures extrêmes [Evolution of proline and chlorophylls of cork oak seedlings (Quercus suber L) subjected to extreme temperatures]. Engineer's dissertation, University Mentouri of Constantine Algeria.

Miller G, Suzuki N, Ciftci-Yilmaz S, Mittler R (2010). Reactive oxygen species homeostasis and signalling during drought and salinity stresses. Plant, Cell and Environment 33:453-467.

MARD (2007). Ministry of Agriculture and Rural Development - The national plan for agricultural and rural development and the fight against desertification. Proceeding of International Workshop of the Pan-African Parliament on the Fight against Desertification, 02 - 04 April 2007, Algiers.

Mohammed RS, Abou Zeid AH, El Hawary SS, Sleem AA, Ashour WE (2014). Flavonoid constituents, cytotoxic and antioxidant activities of Gleditsia triacanthos L. leaves. Saudi Journal of Biology Science 21(6): 547-553.

Nakashima K, Satoh R, Kiyosue T, Yamaguchi-Shinozaki K, Shinozaki $\mathrm{K}$ (1998). A gene encoding proline dehydrogenase is not only induced by proline and hypoosmolarity, but is also developmentally regulated in the reproductive organs of Arabidopsis. Plant Physiology 118:1233-1241.

Nedjraoui D, Bedrani S (2008). La désertification dans les steppes algériennes: causes, impacts et actions de lutte [Desertification in the Algerian steppes: causes, impacts and actions of struggle]. VertigO Revue électronique en sciences de l'environnement http:// journals.openedition.org/vertigo/5375 DOI: 10.4000/vertigo. 5375.

Owusu SA, Schlarbaum S, Carlson JE, Gailing O (2016). Gene flow analyses and identification of full-sib families in isolated populations of Gleditsia triacanthos L Botany 94:523-532.

Papanastasis VP, Platis PD, Dini-Papanastasi O (1998). Effects of age and frequency of cutting on productivity of Mediterranean deciduous fodder tree and shrub plantations. Forest Ecology and Management 110:283-292.

Parida AK, Dagaonkar VS, Phalak MS, Umalkar GV, Aurangabadkar LP (2007). Alterations in photosynthetic pigments, protein and osmotic components in cotton genotypes subjected to short-term drought stress followed by recovery. Plant Biotechnology Reports $1(1) 37-48$.

PDRA (2013). People's Democratic Republic of Algeria - Project for improving ecosystems and means of life in the deserts (ALGDELP) Global Environment Founds (GEF). Retrieved 2018 February from http://documents.banquemondiale.org/curated/ fr/858741468204235242/pdf/E43710EA0FRENC00disclosed0 
592

12050130.pdf.

PDRA (2010). People's Democratic Republic of Algeria-Project CD4CDM Algeria Guide of Projcet developpement of MDP in Algeria. Retrieved 2018 February from www.cd4cdm.org/ .../Algeria/GuideDeveloppementProjetMDPAlgerie.pdf.

Pietrini F, Iannelli MA, Massacci A (2002). Anthocyanin accumulation in the illuminated surface of maize leaves enhances protection from photo-inhibitory risks at low temperature, without further limitation to photosynthesis. Plant Cell \& Environment 25:12511259.

Pinheiro C, Chaves MM, (2011). Photosynthesis and drought: can we make metabolic connections from available data? Journal of Experimental Botany 62:(3)869-882.

Preston RJ, Braham RR (2002). North American trees. Iowa State Press (5th ed), Iowa.

Putod R (1982). Les arbres fourragers: Le févier [Fodder trees: The fevier]. Le Tholonet. Forêt Méditerranéenne 4(1):33-42.

Rakhmanberdyeva RK, Talipova M, Gazizov F, Rakhimov DA (2002). Carbohydrates and lipids of Gleditsia triacanthos seeds. Chemistry of Natural Compound 3(1):24-26.

Rivero RM, Ruiz JM, Garcia PC, Lopez-Lefebre LR, Sanchez E, Romero L (2001). Resistance to cold and heat stress: accumulation of phenolic compounds in tomato and water melon plants. Plant Sciences 160:315-321.

Rosales MA, Ocampo E, Rodríguez-Valentín R (2012). Physiological analysis of common bean (Phaseolus vulgaris $\mathrm{L}$.) cultivars uncovers characteristics related to terminal drought resistance. Plant Physiology and Biochemistry 56:24-34.
Schnabel A, Wendel JF (1998). Cladistic biogeography of Gleditsia (Leguminosae) based on $n d h F$ and rpl16 chloroplast gene sequences. American Journal of Botany 85:1753-1765.

Schnabel A, Hamrick JL (1995). Understanding the population genetic structure of Gleditsia triacanthos L.: the scale and pattern of pollen gene flow. Evolution 49:921-931.

Singleton VL, Rossi IA (1965). Colorimetry of total phenolics with phosphor-molybdic-phosphotungstic acid reagents. American Journal of Enology and Viticulture 16 (3):144-158. Szabo L, Savoure A (2010). Proline: a multifunctional amino acid. Trends in Plant Science 15(2):89-97.

Tattini M, Galardi C, Pinelli P, Massai R, Remorini D, Agati G (2004). Differential acumulation of flavonoids and hydroxycinnamates in leaves of Ligustrum vulgare under excess light and drought stress. New Phytology 163:547-561.

Troll W, Lindesly J (1955). A photometric method for the determination of proline. Journal of Biological Chemistry 215:655660.

Turner NC (1989). Crop water deficits: a decade of progress. Advances in Agronomy 39:1-5.

Turova AD (1974). Medicinal plants of the USSR and their application. Meditsina, Moscow.

Wang CY, Cheng SH, Huei C (1982). Senescence of rice leaves. Plant Physiology 69:1348-1349. 